\title{
Effective Management of Seized and Confiscated Assets as a Condition for Providing Victims with Access to Justice and Fairness of Procedures Used in Criminal Proceedings: International and Russian Experience
}

\author{
Kirill V. Kamchatov ${ }^{1, *}$, Andrey A. Timoshenko², Ekaterina Yu. Kamchatova ${ }^{3}$, Olga \\ V. Buzu ${ }^{4}$
}

\begin{abstract}
${ }^{1}$ Department of scientific support of Prosecutor's supervision over the execution of laws in the implementation of operational investigative activities and participation of the Prosecutor in criminal proceedings of the Research Institute of the University of the Prosecutor's office of the Russian Federation, Moscow, Russian Federation

${ }^{2}$ Department of the University of Prosecutor's office of the Russian Federation, Moscow, Russia

${ }^{3}$ Department of innovation management, State University of management, Moscow, Russian Federation

${ }^{4}$ Technical University of Moldova, Department of Engineering, Management and Valuation of Real Estate

*Corresponding author. Email:radogost2000@mail.ru
\end{abstract}

\begin{abstract}
The purpose of the research is to form a General idea of the management system in the framework of legal procedures for seized and confiscated assets for compensation for damage caused by an offense. The hypothesis of the research is that the national system of management of seized and confiscated assets is lagging the current tasks and trends of legal protection of victims. The objectives of the research are: analysis of the legal basis for regulating the management of seized and confiscated property; generalization of foreign law enforcement practice and recommendations of international organizations on the management of seized and confiscated property; development of proposals for improving the legislation of the Russian Federation. The empirical material is based on various law enforcement acts (resolutions of authorized bodies, decisions and sentences of courts, etc.), the results of a survey of law enforcement and regulatory agencies, and official statistics. The methodological basis of the research is the dialectical method of scientific knowledge, the main General scientific research methods (analysis, synthesis, induction, deduction, analogy, modeling), the comparative legal method, the principle of cognoscibility of objective reality. The main results of the study allow us to comprehensively assess the effectiveness and sufficiency of legal regulation and management practices of seized and confiscated assets in the Russian Federation; to develop the most effective approaches and methods of management of property goods of interest based on the analysis of foreign experience and legislation; to propose a model for building a comprehensive system of management of seized material goods in the Russian Federation, taking into account the specifics of economic and socio-legal factors. The research area consists of legal relations that are formed in the process of organizing and implementing measures aimed at accounting, storage, and sale of assets that have been seized and confiscated based on the facts of committed offenses. Prospects for the studies proceed from the view of the system of management of the seized and confiscated property, on the one hand as a necessary element of the guarantees of the access of the victim to justice, and fundamental fairness of the procedures, taking into account the interests of persons subject to criminal prosecution on the other. The authors proceed from the need to create conditions for making a legal, reasonable and fair management decision in relation to property seized in a criminal case that is of a security nature in relation to criminal proceedings. From these positions, the paper examines the implementation of interim measures taken in the framework of the implementation of the procedural powers of participants in these legal relations.
\end{abstract}

Keywords: seizure of assets, compensation for damage from crime, confiscation, victim of crime, access to justice, fairness of criminal proceedings 


\section{INTRODUCTION}

The paradigm of globalization of the modern world has predetermined the trends of existence and development of both the entire world community and individual States. In these conditions, the main vector of development is market relations, which require all participants to ensure the implementation of the principle of equality. In a situation of constant development of financial, industrial and social institutions, the effective functioning of the international standard - access to justice, as a universal guarantee of protection of any victim of crime, fair consideration and resolution of criminal cases, is of particular importance. The fairness of the final court decision implies compensation for the damage caused by the criminal act. In turn, the provision by state institutions of compensation for damage caused by a crime depends not only on the completeness and speed of the adoption of interim measures, but also on the effective management of the seized and confiscated assets of persons who are subject to criminal prosecution or a final court decision of an indictable nature. It is also important to recognize the need to build a system of guarantees for the application of appropriate procedures for the return of property seized from a person who has previously been brought to criminal responsibility, in a situation where, for objective reasons, he is not found guilty of committing a crime and is subject to rehabilitation.

The urgency of the problem of asset management is also due to the constant increase in the amount of damage from criminal activity, an increase in the total value of property that has been seized and confiscated.

\section{METHODOLOGY}

To form an idea of the Russian and foreign regulatory and legal framework for the management of seized assets, a dialectical method of scientific knowledge was chosen, and the main General scientific research methods were also used: analysis, synthesis, induction, deduction, analogy, and modeling. The comparative legal method was used to determine the possible implementation or incorporation of international standards or practices of foreign legal systems. K140 methodological classifier. The research source base consists of Federal legislation and international sources, law enforcement practices of law enforcement and regulatory agencies, and official statistical indicators. The time frame of the study is 3 years (2017-2019). The volume of the studied units includes more than 150 procedural decisions (decisions, sentences, demands, representations, etc.), more than 200 analytical reports of law enforcement agencies, and more than 100 questionnaires of expert interviews.

\section{DISCUSSION}

Legal basis for the management of seized and confiscated assets in the Russian Federation.

The management of seized and confiscated assets in the Russian Federation is regulated by the norms of various branches of law.

In the sphere of criminal legal regulation, there are General rules for the storage of property that is subject to seizure, by transferring it to the owner, owner or other other person who has been warned about the responsibility for its safety. Confiscated can be a means of committing a crime belonging to the accused; money, valuables, other property, received by criminal means, the income, etc. Enforcement of property penalties arising from the final court decision in terms of ensuring compensation for damage caused by a crime or confiscation of property is assigned to bailiffs.

Handling (storage, accounting, transfer) of items recognized as material evidence is defined by the decree of the Government of the Russian Federation No. 449 of 08.05.2015. The procedure for handling property recognized as material evidence in a criminal case is decided by the court when passing a sentence or other final decision on the case. The law defines the procedure for the sale or destruction of items that are material evidence, the storage of which is difficult until the end of a criminal case or during a criminal case [1].

In accordance with the civil procedure, the seizure of property acts as a measure to secure the claim (issued in the form of a court ruling), which is immediately given in accordance with the section. A judicial act is the basis for issuing a writ of execution to the plaintiff. The court reports on the measures taken to state authorities or local self-government bodies that register assets and rights to them (restriction, encumbrance, transfer, termination).

For comparison, in accordance with arbitration law, the seizure of assets is imposed by the court and consists in immediately ensuring the safety of this property, specified in the court's decision to designated persons. According to administrative law, the transfer of seized assets is also possible to specially designated persons responsible for storage.

The seizure of the property of a legal entity (attracted under article 19.28 of the administrative Code of the Russian Federation) has its own specifics: the arrest is applied only by a judge's decision, which defines restrictions related to the disposal, possession and use of the seized assets. This decision is enforced in accordance with the requirements of Federal legislation on enforcement proceedings.

According to the customs (payment of customs duties, special, anti-dumping, countervailing duties, interest and penalties) and tax (collection of tax, penalties, fines) Federal legislation, when assets are seized, the procedure 
for managing them is determined only by the General approach to the location and assessment of the seized property.

The enforcement of judgments a garnishment under the code, administrative code, code of civil procedure of the $\mathrm{RF}$ and APC RF, in accordance with the legislation on Executive manufacture of service of court bailiffs. The decision to seize assets indicates the address of the person who is obliged to protect and store the property entrusted to him. Such a decision is mandatory for the investigator, inquirer, and other natural and legal person specified in the judge's decision.

Asset management under the confiscation of forced gratuitous appeal to the Federal property or property subject of the Russian Federation has not withdrawn from circulation things (belonging on the property right to the person brought to administrative liability for this administrative offence and recognized in court guilty of its Commission) established by the Government of the Russian Federation dated 29.05.2003 № 311 "About the accounting treatment, estimates and orders the property turned into the property of the state."

Federal Agency for state property management (Rosimushchestvo) implements seized, seized and confiscated property in accordance with the procedure established by Russian law [2, 3]. The procedure for converting property into state ownership and selling this property is established by resolutions of the Government of the Russian Federation [4]. The list of seized or confiscated property to be sold is available on the official website of the Federal property management Agency.

Thus, the scope and content of the legal regulation of the sphere of legal relations under consideration indicate that the management of seized and confiscated assets is within the competence of various state authorities, which exercise their respective powers on the basis of a wide range of legal acts regulating various aspects of their activities.

Foreign law enforcement practices and recommendations of international organizations on the management of seized and confiscated assets.

As a General recommendation for implementing the provisions of article 31 of the UN Convention against corruption of 31.10 .2003 (hereinafter referred to as the Convention against corruption), it is noted that it is necessary to improve the management of seized and confiscated property, especially complex assets, and to consider the possibility of States creating special bodies to manage them [5]. Similar recommendations on countering corruption were made within the world Bank [6].

During the preparation of the country profiles on the Convention against corruption, UN experts noted the most common difficulties encountered in the management of seized and confiscated assets, as well as in their return to their rightful owners: lack of coordination between police investigators and employees of asset management structures at the planning stage prior to the seizure of property; lack of specialists in the management of seized assets; difficulties arising from the need to coordinate the actions of various competent authorities; insufficient public awareness and citizens ' disbelief in the success of this activity [7]. The literature also notes the need to study the prospects for assessing the need to protect (restrict) the third generation of human rights - rights based on collective property ownership [8] in connection with the fight against corruption. After all, any criminal prosecution of the owners of a Corporation has an impact on the value of its securities [9].

The conference of the States parties to the Convention against corruption, in its resolution, stipulated the need to ensure an active and timely exchange of information on the issue under consideration. In some countries, the use of networks of asset recovery practitioners, including those dealing with confiscation issues, is noted [10].

UN experts noted that, globally, the only resource for systematically tracking the efforts of prosecution authorities aimed at recovering assets obtained as a result of corruption remains the database "monitoring asset recovery" [11]. This information source is a universal source of information created to combine the efforts of national authorities and international organizations [12].

The UN recommendations point to the need to define in state law and practice a pre-arrest planning procedure, formulate criteria or recommendations for when to seize property or freeze assets, taking into account, for example, the expected resource requirements for servicing, the estimated value of the assets to be seized, and the purpose of the interim measure from a law enforcement point of view.

Taking into account the cost of asset management and the time required to make a final decision, the alternative options include the possibility of selling or disposing of the property before confiscation (also referred to as presale, interim sale, early sale, or prospective sale).

Selling or disposing of property for certain categories of assets, such as: perishable assets; rapidly depreciating assets; assets whose storage or maintenance costs are disproportionate to their value; assets that are difficult to manage or require special conditions or qualifications that are difficult to secure; assets that are easily replaced; assets whose owner has disappeared, possibly before confiscation, even without the owner's consent. As noted above, a similar procedure is provided for in the Russian Federation.

In some countries for the management of complex assets control specially appointed by the court, which can be brought by the contractors from the private sector.

As approaches to the disposal of seized and confiscated property, it was noted that it is necessary to establish national funds for the placement of confiscated assets; to seek the possibility of re-using the confiscated property for public needs and the needs of law enforcement agencies. The vast majority of member States of the European Union use the sale of confiscated illegal assets as the main mechanism, followed by the transfer of the 
proceeds to state budgets or specialized funds for compensation of victims of crime.

The transfer of confiscated income to the national Fund may be the most cost-effective form of asset management that uses General approval and supervision mechanisms. On the other hand, channeling proceeds to specific programs creates a direct link between asset forfeiture and specific program goals, such as compensation for victims, which facilitates monitoring the use of confiscated assets and makes their use targeted [13].

In accordance with FATF recommendation 38, "Mutual legal assistance: freezing and confiscation", countries should have effective mechanisms for managing such property or assets of appropriate value, as well as arrangements for coordinating procedures for the seizure and confiscation of proceeds, which should include a section on confiscated assets [14].

Currently, a variety of institutional mechanisms have been developed and put into practice for the cost-effective preservation of seized assets and ensuring maximum return on confiscated assets. It should be noted that almost all member States of the European Union have legal provisions aimed at preserving and optimizing seized assets, as well as minimizing the costs of their maintenance, but it is not possible to identify any unified approach to regulation [15].

Article 10 of the European Union Directive no. 2014/42/EU of 03.04.2014 on the management of frozen and confiscated property contains a number of important approaches for member States, namely the creation of a centralized authority and mechanisms for the management of seized and confiscated property; the possibility of selling and selling this property or using the confiscated property for public interests and social purposes. The purpose of seizure and confiscation is recognized as instruments of crime, assets obtained by criminal means (direct income, indirect benefits, funds received as a result of subsequent financial reinvestment, legal documents or acts confirming ownership, receivables, etc.) [16].

Analysis of foreign practice allows us to identify a number of approaches to the management of seized and confiscated property:

asset management services within an active law enforcement Agency or authorized Ministry (States with such mechanisms include Belgium, the Czech Republic, the Netherlands, Thailand and the United States of America). In some of these countries, the asset management service, in addition to its normal asset management functions, is also responsible for facilitating the use of asset forfeiture as a law enforcement tool. Such services play a role in asset tracking, training and advising other practitioners on confiscation issues, serving as a focal point for international cooperation in asset recovery, pre-arrest planning, support during judicial proceedings, or distribution of proceeds;

asset management services located in public institutions with additional functions related to property management (States with such mechanisms include Australia, Mexico, and New Zealand). Such services make full use of the specialized and multi-functional capabilities normally available in property management services;

independent asset management services (States with such mechanisms include Canada, Colombia, France, and Honduras). This option is considered particularly desirable when the scale of asset forfeiture has reached a level that justifies the cost of operating such a service. The creation of an independent asset management service may also be motivated by a desire to separate the functions of investigation and prosecutorial supervision from the functions of asset management. All agencies should make continuous efforts to ensure smooth communication between investigative, prosecutorial and management authorities [12].

For example, in Canada, the government of Canada's Seized Property Management Directorate (1993) collaborates with local and international law enforcement agencies in locating, seizing, managing, storing and disposing of criminally obtained confiscated property [17, 18]. Prior to the immediate seizure of property, the Directorate performs a financial analysis of the property, analyzes and evaluates the best method of protecting and maintaining the value of assets, and estimates the costs associated with asset management. If necessary, the Directorate performs logistics functions (for example, towing), storage of seized property, and management of the seized business. Sale of confiscated assets (movable assets such as electronics, cars, furniture and jewelry), sold publicly or through auction; funds are distributed in accordance with the rules for the division of confiscated property; real estate items, such as buildings, houses, and land, are sold using public procurement services in Canada (PSPC) or private sector brokerage agencies [19]. An example of a centralized approach to the management of confiscated property for public (but not social) purposes is the experience of the United States Department of justice (hereinafter referred to as the United States). For this purpose, under the Comprehensive crime control act of 1984, the confiscated assets Fund is used, consisting of a Fund that was created to store the currency (Assets Forfeiture Fund, AFF) received from the confiscation, and the seized Asst deposit Fund (SADF). SADF controls seized funds and other property with investment authority until the end of the criminal trial. Most of AFF's revenue from the confiscation of monetary assets and the sale of confiscated property is used for public purposes, for example, to cover operating expenses under government programs (for the seizure of property, its inventory, evaluation, transportation, storage, maintenance, disposal, etc.).

In the United States, the procedure for storing seized cars is set depending on their cost. Cars that cost less than $\$$ 500 are subject to recycling. Cars worth more than 10 thousand US dollars are stored in specialized Parking lots. Expensive cars in order to maintain their original technical condition are additionally serviced by monthly engine 
start-up and a short period of operation by responsible persons.

The Prosecutor's office of the Kingdom of Belgium from September 2003, a Central office for seizure and confiscation of assets, responsible for the management of seized property and the enforcement of decisions on confiscation, collection and processing of all data relating to the seizure and safekeeping and storage, as well as confiscation issues and relevant court decisions (in the database), implementation and sales of property, maintenance and management of which is complicated (for example, populated by tenants of the building) or which is subject to rapid deterioration (e.g., vehicle). The Department also makes low-risk financial investments to preserve the value of seized assets. Since 2014, the office has focused on asset recovery, in particular the search for assets that can be confiscated [20].

The process of selling seized, and confiscated property is increasingly carried out through information and telecommunications networks. For example, in Italy, goods that are admitted to civil circulation and confiscated in cases of administrative offenses, or whose owner is not identified, are sold at electronic auctions, with the initial price of the property can be either fixed or equal to zero. Methods of reuse of proceeds from confiscated assets through specialized funds (programs) also bring positive results and benefit society.

The difference between the mechanism for managing seized and confiscated assets in the Russian Federation is that funds received from the sale of such property are transferred to the Federal budget. In Italy, the United States, the United Kingdom and a number of other countries, proceeds from the confiscation of financial assets and the sale of seized property go to a special Fund that not only manages them in the interests of society and the state, but also monitors their timely implementation. For example, in The Australian Union, confiscated assets from criminal activity are transferred to a specially established trust Fund for confiscated assets (the Confidential Assets Account) [21], which is managed by the Australian financial Security Authority.

A systematic approach to the management of seized and confiscated property is used in the Republic of Belarus, where the decree of the President of the Republic of Belarus No. 63 of 19.02.2016 approved the Regulation on the procedure for accounting, storage, evaluation and sale of property seized, seized or converted to state revenue [22].

\section{RESULTS}

I. Considering the best foreign law enforcement practices and recommendations of international organizations, the following approaches to building an effective management system for seized and confiscated property can be identified:
- defining transparency, traceability, control and accountability of the procedures carried out from the stage of withdrawal to the actual disposal of assets as the main criterion for building an asset management system;

- creation of centralized systems and databases for asset registration throughout the management process, including electronic interagency interaction systems, electronic bidding systems, which will make the entire asset management process open, accessible and traceable at all levels;

- creation of an accountable, qualified service for the management of seized and confiscated assets;

- determining whether assets should be seized and determining the best ways to enforce the relevant decision, including selecting the asset Manager and evaluating confiscation scenarios;

- reduction of associated costs associated with asset management, including storage costs, and preservation of the value of income from the sale of assets until the final decision is made;

- maintaining assets at minimum costs and obtaining maximum revenue from their sale, assessing the proportionality of the costs inevitably associated with the management of seized and confiscated property and the estimated cost of its sale;

- fixing in legislation the main preferred options for the distribution of assets, which may include crediting to the state budget or use for specific purposes, including the return or payment of compensation to victims, use for social needs and financing of law enforcement activities;

- increasing public confidence in the state system of management of seized and confiscated assets, the possibility of using this property for both public and social purposes.

II. An Analysis of Russian practice makes it possible to make the following suggestions for improving certain aspects of the management of seized and confiscated assets:

1. special attention Should be paid to the practice of storing physical evidence. Every year, investigators make 250-300 thousand such decisions, while prosecutors identify at least 7 thousand violations of the procedure for storing and handling seized valuables, items and documents. Violations related to improper handling of large-sized and perishable goods seized in criminal cases, non-compliance with fire safety requirements of premises, lack of necessary technical storage conditions are established; transfer of seized assets for storage to organizations involved in commercial turnover, free of charge; illegal destruction and sale of material evidence seized in criminal cases; unsubstantiated assessment and transfer of seized assets for sale.

In most cases, such situations are caused by the absence of an established procedure for financing investigative bodies for the purpose of ensuring the safety of seized property in the form of perishable and bulky goods (food, cars, machinery, etc.). the Relevant actions of officials entail damage to the property interests of the state, 
including as a result of legal grounds for filing claims against the Russian Federation by the legal owners of the property.

2. Analysis of law enforcement practice shows that there is no unified system of accounting for seized and confiscated property in the Russian Federation. Information provided in state and departmental statistics on damage caused by a crime and interim measures taken at the pre-trial stage of criminal proceedings are not correlated with each other. The solution to this problem is proposed by creating a consolidated detailed record (a single database) of seized property, including those transferred for safekeeping, which can accumulate information about its subsequent movement after its fate is resolved by a procedural decision of a law enforcement Agency or court on confiscation, when and how it was implemented, on return to the rightful owner, etc.

3.in the event of confiscation or conversion to state ownership of property, the entire chain of subsequent actions to dispose of it is carried out at the expense of the state (transportation, storage, examination, evaluation, sale or destruction). As a result, significant expenditure obligations are formed for the Federal budget. And since the property is already state property after confiscation and conversion to state ownership, these costs do not relate to procedural expenses, which can be compensated by collecting them from the former owners of such property in the framework of criminal and other procedural legislation.

At the same time, the main asset for sale for the main purpose is used goods (i.e. those that have already been released into circulation on the territory of the Russian Federation), as well as vehicles and property obtained as a result of corruption violations, a market assessment that indicates a significant reduction in their value compared to new analogues. Based on the results of the market evaluation of the seized goods in accordance with the existing standards, fraud can be excluded in the sale of such property.

4.on the issue of improving the mechanisms of disposal (sale) of state-owned real estate, which is a housing stock, it is proposed as a priority method of disposal to establish the transfer of housing stock objects to the authorized authorities for subsequent provision of housing conditions in need of improvement under social employment contracts.

5. Another important issue is the improvement of criminal-legal regulation of questions of management of the seized and confiscated property. The criminal code of the Russian Federation provides for liability for unlawful actions with property subject to arrest or confiscation (article 312 of the criminal code of the Russian Federation).

However, article 312 of the criminal code does not cover all cases of illegal actions with seized and confiscated assets. Often there are situations when the seized or confiscated property is deliberately priced below the market price, so that its sale at an undervalued cost entails damage to the state in the form of lost profits. If the specified actions are committed in a large amount (over 250 thousand rubles) by a group of persons by prior agreement or organized group, or with damage in a particularly large amount (over 1 million rubles). They are subject to qualification under article 165 of the criminal code of the Russian Federation.

However, the provisions of article 165 of the criminal code does not fix as a qualified crime, the Commission of such acts by a person using his official position that is a legal flaw, because it does not provide proper differentiation of criminal responsibility, and violates the uniformity of legal regulation, since article 159-160 of the criminal code enshrine the Commission of a crime by a person using his official position as skilled formulations.

\section{CONCLUSION}

Today's realities strongly require legislation and law enforcement agencies to make comprehensive decisions that meet advanced quality standards, the needs of society and the state. It is obvious that the solution of the accumulated problems in this area should be carried out by developing comprehensive approaches, including those based on international experience, taking into account the peculiarities of the national legal system and interrelated factors of a social and economic nature.

Improvement of the current management procedure is possible through the adoption of the Federal law on the management of seized and confiscated property, which regulates the common rules and mechanisms for the management (withdrawal from circulation, accounting, evaluation, registration, financing, storage, sale, etc.) of seized, confiscated and other seized assets subject to state ownership.

For the purpose of rapid implementation of the seized and confiscated property and its actual execution, it seems appropriate to create a single electronic platform for the sale of seized, confiscated and other seized property on the basis of the Internet. It is possible to use a single information system as a model (sample) (http://zakupki.gov.ru), electronic platforms and specialized electronic platforms, the implemented electronic platform of Rosimushchestvo.

It seems reasonable to create divisions in law enforcement agencies responsible for the management of seized and confiscated property. As a pilot project, you can propose the creation of a register of the property of the arrested person in the manner prescribed by the code of criminal procedure, which lay on the Federal property Agency under the supervision of the General Prosecutor of the Russian Federation (with reference to the provisions of article 51 of the Federal law of 17.01.1992 № 2202-1 "On the procuracy of the Russian Federation"). 


\section{THE PERSPECTIVES OF THE RESEARCH}

Effective management of seized and confiscated assets is an important element in building a promising model for protecting the rights of participants in criminal proceedings, ensuring their unhindered access to justice. However, the practical implementation of this universal guarantee depends on other related factors, primarily on the legal status of the main participants in legal relations, officials of the preliminary investigation and Prosecutor's offices, and the understanding of the victim of a crime as an institution that requires a comprehensive further study.

\section{ACKNOWLEDGMENT}

The authors Express their gratitude to the leadership Of the University of the Prosecutor's office of the Russian Federation for creating conditions for conducting a comprehensive and high-quality scientific search.

\section{REFERENCES}

[1] Decree of the Government of the Russian Federation from 23.08.2012, No 848, Available at: http://www.consultant.ru/document/cons_doc_LAW_1 $34384 /$.

[2] Decree of the President of the Russian Federation from 12.05.2008, No 724, Available at: http://www.consultant.ru/document/cons_doc_LAW_7 $6855 /$.

[3] Decree of the Russian Federation government from 05.06.2008, No 432, Available at: http://www.consultant.ru/document/cons_doc_LAW_7 $7490 \%$.

[4] Decree of the Russian Federation government from 29.05.2003, No 311, Available at: http://www.consultant.ru/document/cons_doc_LAW_4 2464/.

[5] Review of the Organization's implementation of the Convention United Nations against corruption from 14.09.2018, Available at: https://clck.ru/HaVCz.

[6] R.A. Saadi, D.O. Machado, Values of corruption: management of seized and confiscated assets, Revista DIREITO GV Law Review 13(1.2) (2017) 484-519. DOI: $10.1590 / 2317-6172201719$
[7] Report of the meeting of the open-ended intergovernmental working group on asset recovery from 02.07.2019, Available at: https://clck.ru/HbJGQ.

[8] C.M. Dickerson, Culture and Trans-Border Effects: Northern Individualism Meets ThirdGeneration Human Rights, Rutgers Law Review 54 (2002) 865 .

[9] Chen Yunsen, Xie Yuan, You Hong, Zhang Yanan, Does crackdown on corruption reduce stock price crash risk? Evidence from China, Journal of Corporate Finance August (2018) 125-141. DOI: $10.2139 /$ ssrn.3237345.

[10] Provisions of the open ended intergovernmental working group on asset recovery approved by the Convention United Nations against corruption from 05.04.2018, Available at: https://clck.ru/HbGZ7.

[11] Report on the implementation of the mandates of the working group on asset recovery of the Convention United Nations against corruption from 20.03.2019, Available at: https://clck.ru/HcRFG.

[12] R. Ivory, Corruption, Asset Recovery, and the Protection of Property in Public International Law, Cambridge University Press, 2014. DOI: 10.1017/CBO9781107415737

[13] The results of the forum of the Convention United Nations against corruption from 26.03.2018, Available at: https://clck.ru/Htbqe.

[14] FATF 2012-2019. International Standards on Combating Money Laundering and the Financing of Terrorism \& Proliferation, FATF, Paris, France, Available at: www.fatfgafi.org/recommendations.html.

[15] N.A. Golovanova, Questions of management of confiscated property, Journal of Russian law 10 (2016) 78-89. DOI: $10.12737 / 21525$

[16] Directive 2014/42/EU of the European Parliament and of the Council of 3 April 2014, Available at: https://clck.ru/Htc4i.

[17] The law On the management of seized property approved by the Ministry of justice of Canada from 23.06.1993, Available at:, https://lawslois.justice.gc.ca/eng/acts/S-8.3/page-1.html. 
[18] Canada's seized property management Act from 01.09.1993, Available at: https://www.tpsgcpwgsc.gc.ca/app-acq/gbs-spm/index-eng.html.

[19] V.I. Lafitskiy, A.M. Tsirin, N.A. Golovanova, Prospects for the application of mechanisms for freezing, seizing and confiscating criminal assets, and mechanisms for managing confiscated assets (comparative legal research): a monograph, 2014.

[20] FATF Anti-money laundering and counterterrorist financing measures. FATF, Belgium, 2015, Available at: https://www.fatfgafi.org/media/fatf/documents/reports/mer4/MutualEvaluation-Report-Belgium-2015.pdf.

[21] Australian Criminal procedure act of 2002, Available at:

https://www.legislation.gov.au/Details/C2019C00006.

[22] Decree of the President of the Republic of Belarus No. 63 from 19.02.2016, Available at: http://base.spinform.ru/show_doc.fwx?rgn=84039\#A4 LMONPDOT. 